\title{
Optimization of DNA extraction and PCR protocols for plants with high Phenolics: Bael, Mango, Pomegranate as examples
}

\author{
C. K. Pathirana ${ }^{1,2,3}$, C. H. W. M. R. B. Chandrasekara ${ }^{3}$, S. R. M. R. Attanayake ${ }^{2,3}$, W. A. P. Weerakkody ${ }^{1}$, J. P. \\ Eeswara $^{1}$ and P. C. G. Bandaranayake ${ }^{3 *}$ \\ ${ }^{1}$ Department of Crop Science, Faculty of Agriculture, University of Peradeniya, Peradeniya, 20400, Sri Lanka \\ ${ }^{2}$ Postgraduate Institute of Agriculture, University of Peradeniya, Peradeniya, 20400, Sri Lanka \\ ${ }^{3}$ Agricultural Biotechnology Centre, Faculty of Agriculture, University of Peradeniya, Peradeniya, 20400, Sri Lanka
}

Received:14/10/2017; Accepted:17/01/2018

\begin{abstract}
The genetic studies of tropical tree species containing high amount of phenols are greatly hampered by the inability to extract sufficient quantities of high quality DNA and the presence of PCR inhibitors in extracted DNA samples. While there are some DNA extraction and PCR protocols for such species, no consistency in results. Hence, optimization of such protocols is a prerequisite for conducting research studies on tropical flora. This study reports the optimization of cheaper DNA extraction and PCR procedures for plants having high amount of phenolic compounds and PCR inhibitors. Three fruit crop species, Bael (Aegle marmelos L. Correa), Pomegranate (Punica granatum L.) and Mango (Mangifera indica L.), with distinctly diverse secondary metabolic profiles, were used as examples. The CTAB DNA extraction method, with some modifications, was compared with two commercially available DNA extraction kits namely; Promega Wizard ${ }^{\circledR}$ Genomic DNA purification kit and QIAGEN DNeasy ${ }^{\circledR}$ Plant Mini kit. DNA from three to five genotypes from each species was extracted from each method and the quality and quantity were assessed. Spermidine was added to the PCR mix at the rate of $0.8 \mu \mathrm{M}$ to block the PCR inhibitors and the DNA samples were amplified using universal plant barcoding primer pair $r b c L$, and SSR or ISSR primers. The modified CTAB method resulted significantly higher quantity of quality DNA in all samples compared to two commercial kits. Henceforth DNA extracted from CTAB method, and the two commercial kits were used to precede PCR. However, expected bands were not generated in regular PCR. Interestingly, the inclusion of spermidine amplified the relevant band/s in relatively easy PCR reactions such as $r b c L$, as well as trickier reactions such as SSR and ISSR. These results suggest that cheaper alternative procedures used in this research study could be used successfully for the range of applications in plants with array of secondary metabolic profiles.
\end{abstract}

Keywords: Aegle marmelos L. Correa, Punica granatum L., Mangifera indica L., DNA extraction, Spermidine, PCR inhibitors, phenolic compounds.

\section{INTRODUCTION}

Optimization of DNA extraction and PCR protocols are the basic and most important preliminary steps of any molecular biological application. Secondary metabolites such as phenolic compounds present in plants play important roles in their defence mechanisms against predators and pathogens (War et al., 2012). These secondary metabolites often hinder the extraction of high quality DNA and successful PCR amplification (Pirttila et al., 2001). While some of these compounds directly bind or intercalate with DNA molecule, others inhibit the activity of DNA manipulating enzymes such as Taq DNA polymerase (Manoj et al., 2007; Schrader et al., 2012).

There are many DNA extraction methods available from quick and dirty to highly purified column-based commercial kits. Most of these methods and commercial extraction kits are optimized for model plant species such as Arabidopsis thaliana and Rice (Oryza sativa) (Roychowdhury et al., 2012). Therefore, DNA extraction protocols have to be optimized for non-model plants. If one protocol works for a range of species, that would save time and cost required for such optimization steps and expedite the genetic improvement of such plant species.

The polyamines such as spermine and spermidine have been found to increase the success of PCR for DNA extracted from plants such as barley (Ahokas and Erkkila, 1993), cotton (Wan and Wilkins, 1993) and pomegranates (Ono et al.,2012). Although these studies reported different concentrations of PCR enhancers, it would be beneficial to optimize a protocol applicable for range of plant species with phytochemical diversity. Cetyltrimethyl ammonium bromide (CTAB), based methods originally described by Doyle (1987) are more popular among available DNA extraction protocols. However sometimes CTAB method does not yield good quality DNA especially for tropical plant species and therefore in the present study, the original CTAB method was further optimized and it was compared with the commercially available kits. PCR protocol was optimized by incorporating spermidine (Analytical grade) at the concentration of $0.8 \mu \mathrm{M}$.

Three tropical fruit crop species bael (Aegle marmelos L), mango (Mangifera indica) and pomegranate (Punica granatum) with high total phenol contents and distinct secondary metabolic profiles were used for the protocol optimization in the present study. Bael consists of alkaloids, coumarins, terpenoids, fatty acids amino acids, $\gamma$-sitosterol, aegelin, lupeol, rutin, marmesinin, $\beta$-sitosterol, flavone, glycoside, oisopentenly lhalfordiol, marmeline and phenyl 
ethyl cinnamamides (Yadav and Chanotia, 2009) while mango contains protocatechic acid, catechin, mangiferin, alanine, glycine, $\gamma$-aminobutyric acid, kinic acid, shikimic acid and the tetracyclic triterpenoids cycloart-24-en3ß,26diol, 3-ketodammar-24 (E)-en-20S,26-diol, C-24 epimers of cycloart-25 en 3 $\beta, 24,27$-triol and cycloartan33,24,27-triol (Shah et al., 2010). Punicalagin $\alpha$ and $\beta$ are considered as major compounds contribute to the high phenolic activity in pomegranate (Punica granatum) (Mohammad and Kashani, 2012; Viuda-Martos et al., 2010). Morever these three species are important medicinally and economically awaiting further research studies from genetic characterisation to crop improvement in local context. Therefore, objective of the present study was to optimize the DNA extraction and PCR protocols for bael, mango and pomegranate.

\section{MATERIALS AND METHODS}

\section{Plant materials collection}

Immature leaves from five elite bale accessions (Department of Agriculture, Sri Lanka, 2017), four pomegranate selections (two Sri Lankan selections, a Chinese selection and an exotic variety; Wonderful) and stem bark from three Karthakollomban mango accessions were collected. They were ground into fine powder using liquid nitrogen and stored in $-80{ }^{\circ} \mathrm{C}$.

\section{DNA Extraction}

\section{CTAB method}

About $300 \mathrm{mg}$ of finely ground plant materials were mixed with $500 \mu \mathrm{L}$ pre-warmed $2 \times$ CTAB extraction buffer $(50$ $\mathrm{mM}$ CTAB, $950 \mathrm{mM} \mathrm{NaCl}, 100 \mathrm{mM}$ Tris $\mathrm{pH} 8.0$ and 20 mM EDTA pH 8.0 and $0.2 \% \beta$ mercaptoethanol) and incubated for $1 \mathrm{~h}$ at $60^{\circ} \mathrm{C}$ while mixing at every 15 mins. Then $500 \mu \mathrm{L}$ of chloroform/ isoamyl alcohol (24:1) was added and centrifuged at $12000 \mathrm{rpm}$ for $15 \mathrm{~min}$. The supernatant was transferred to a fresh tube and $500 \mu \mathrm{L}$ of isopropanol was added. Then it was incubated at $-20{ }^{\circ} \mathrm{C}$ for $30 \mathrm{~min}$. and centrifuged at $12000 \mathrm{rpm}$ for $5 \mathrm{mins}$. The supernatant was discarded and the DNA pellet was washed with $500 \mu \mathrm{L}$ of $70 \%$ alcohol followed by air drying. The DNA pellet was re-suspended using $30 \mu \mathrm{L}$ of nuclease free water and stored at $-20{ }^{\circ} \mathrm{C}$. Chloroform/isoamyl alcohol (24:1) extraction was repeated one more time as the minor modification to the originally described method.

\section{Commercial extraction kits}

The genomic DNA extraction from ground leaf and stem bark materials were also conducted using two commercially available kits, Promega Wizard $\AA$ Genomic DNA Purification (Cat. No: A1120) and QIAGEN DNeasy ${ }^{\circledR}$ Plant Mini (Cat. No.: 69104), following the manufacturers guidelines.

\section{DNA quantification and assessment of quality}

The quantity of isolated total genomic DNA was determined using NanoDrop spectrophotometer (Nano2000, Thermoscientific). The quality of samples was assessed with the 260/280 and 260/230 readings given by the NanoDrop spectrophotometer and further verified by using $1 \%$ agarose gel electrophoresis.

\section{PCR}

Two different PCRs were carried out for each sample. PCR amplification was done with universal barcoding primer pair $r b c \mathrm{~L}$, (Forward: 'ATGTCACCACAAACAGAGACTAAAGC3', and Reverse: 'CTTCTGCTACAAATAAGAATCGATCTC3') (Kress and Erickson, 2007) and ISSR primers or SSR primer pairs (Table 01). PCR was carried out in a $25 \mu \mathrm{L}$ reaction volume containing $1 \times \mathrm{PCR}$ buffer, $1.5 \mathrm{mM} \mathrm{MgCl}_{2}$, $200 \mu \mathrm{M}$ dNTP (Promega, Cat No: U1515), $0.2 \mu \mathrm{M}$ of each primer (Integrated DNA technologies), 50 ng of DNA, 0.8 $\mu \mathrm{M}$ spermidine and 1 Unit GoTaq FlexiDNA polymerase (Promega, Cat No: M8295). Same reactions were performed in the absence of spermidine. The PCR cycle consisted of $94{ }^{\circ} \mathrm{C}$ of initial denaturation for $5 \mathrm{~min}$, followed by 35 cycles of $94{ }^{\circ} \mathrm{C}$ for $1 \mathrm{~min}, 55^{\circ} \mathrm{C}$ for $30 \mathrm{sec}$ and $72{ }^{\circ} \mathrm{C}$ for 1 min and final extension at $72{ }^{\circ} \mathrm{C}$ for $5 \mathrm{~min}$. A total of $10 \mu \mathrm{L}$ from each PCR product was separated using 2\% Agarose gels containing $0.5 \mu \mathrm{g} / \mathrm{mL}$ ethidium bromide.

\section{RESULTS AND DISCUSSION}

Applications of PCR in plant research are unlimited and isolation of high quality DNA is a prerequisite for PCR amplification (Pirttila et al., 2001). However, unlike in animals or microbes, DNA isolated from plants is usually contaminated with various secondary metabolites.

Table 1: SSR and ISSR markers used for the PCR.

\begin{tabular}{|c|c|c|}
\hline Species & Primer & Sequence \\
\hline Bael & $\begin{array}{l}\text { SSR } \\
\text { (Rutaceae family specific) }\end{array}$ & $\begin{array}{l}\text { NTCP9 Forward 5'CTTCCAAGCTAACGATGC3' } \\
\text { NTCP9 Reverse 5'CTGTCCTATCCATTAGACAATG3 }\end{array}$ \\
\hline Pomegranate & ISSR 842 & 5'GAG AGA GAG AGA GAG AYG3' \\
\hline Mango & $\begin{array}{l}\text { SSR } 84 \\
\text { (Mangifera indica } \text { species specific) }\end{array}$ & $\begin{array}{l}\text { Forward 5'ACTGCCACCGTGGAAAGTAG3' } \\
\text { Reverse 5'ACTGCCACCGTGGAAAGTAG3' }\end{array}$ \\
\hline
\end{tabular}


Co-isolation of polysaccharides, polyphenols, RNA and other secondary metabolites interfere with PCR amplification (Demeke and Jenkins, 2010, Sahu et al., 2012). Polyphenolic compounds interact irreversibly with DNA, resulting inability of different modifying enzymes to manipulate the DNA (Manoj et al., 2007). Polysaccharides present in isolates make the DNA solution highly viscous and make it difficult for pipetting (Fang et al., 1992).

The removal of PCR inhibitors (Fredricks and Relman, 1998) and use of spermidine (Wang et al., 2012) to improve the PCR efficiency are previously reported. For example, in barley (Ahokas and Erkkila, 1993), cotton (Wan and Wilkins, 1993), pomegranate (Ono et al., 2012) and human stool samples (Roperch et al., 2015, Kikuchi et al., 2010). However, the quantity per reaction varies in different applications reported. Therefore, here we present and discuss an optimized CTAB based DNA extraction protocol and spermidine unified PCR protocol applicable for a wide range of plant species with different secondary metabolic profiles.

\section{DNA extraction}

Since allocation of funds for research work is limited in developing countries like Sri Lanka, scientists should track into low-cost methodologies. In that regard, it would be more beneficial to improve CTAB extraction procedure rather than optimizing expensive column based methods to collect good quality DNA. Even in the long run, low

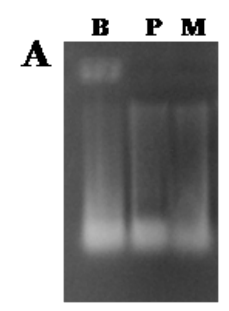

$\begin{array}{lllllllllllllll}\text { L } & \text { B1 } & \text { B2 } & \text { B3 } & \text { B4 } & \text { B5 } & \text { P1 } & \text { P2 } & \text { P3 } & \text { P4 } & \text { M1 } & \text { M2 } & \text { M3 } & \text { L }\end{array}$

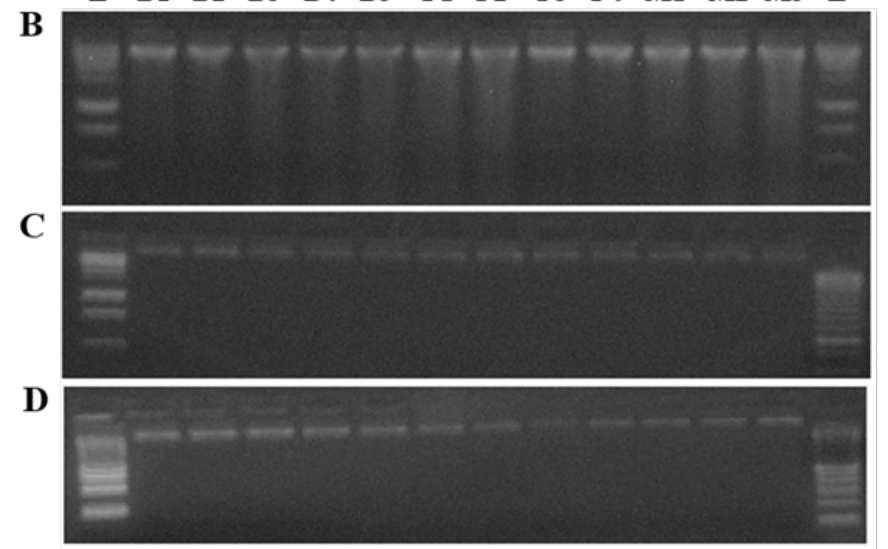

Figure 1: Agarose (1\%) gel electrophoresis of genomic DNA extracted from different methods A: CTAB Method (ladders are not shown and DNA samples of three species were separately electrophoresed); B: Modified CTAB method, C: Promega Wizard $\mathbb{R}$ Genomic DNA Purification kit, D: QIAGEN DNeasy ${ }^{\circledR}$ Plant Mini kit. L: 1kb DNA molecular weight marker (cat no. promega G571A), B1, B2, B3, B4, B5: five elite accessions of Bael, P1, P2, P3, P4 : four selections of Pomegranate, M1, M2 and M3: three selections of mango.

Table 2: Assessment of quality and quantity of extracted DNA

\begin{tabular}{|c|c|c|c|c|}
\hline Species & DNA extraction method & DNA concentration $(\mathrm{ng} / \mu \mathrm{L})$ & $260 / 280$ & $260 / 230$ \\
\hline \multirow{3}{*}{ Bael } & CTAB* & $1250^{\mathrm{a}}$ & 1.71 & 0.92 \\
\hline & Promega Wizard ${ }^{\circledR}$ Genomic DNA Purification kit & $85^{\mathrm{b}}$ & 1.75 & 1.12 \\
\hline & QIAGEN DNeasy® Plant Mini kit & $82^{b}$ & 1.79 & 1.31 \\
\hline \multirow{3}{*}{ Pomegranate } & CTAB* & $1300^{\mathrm{a}}$ & 1.65 & 0.82 \\
\hline & Promega Wizard ${ }^{\circledR}$ Genomic DNA Purification kit & $65^{\mathrm{b}}$ & 1.76 & 0.92 \\
\hline & QIAGEN Dneasy® Plant Mini kit & $87^{\mathrm{b}}$ & 1.81 & 0.87 \\
\hline \multirow{3}{*}{ Mango } & CTAB* & $1150^{\mathrm{a}}$ & 1.50 & 0.85 \\
\hline & Promega Wizard ${ }^{\circledR}$ Genomic DNA Purification kit & $78^{\mathrm{b}}$ & 1.72 & 0.98 \\
\hline & QIAGEN Dneasy ${ }^{\circledR}$ Plant Mini kit & $99^{\mathrm{b}}$ & 1.76 & 0.87 \\
\hline
\end{tabular}

* The modified CTAB method was used.

Means denoted by the same letter within the column are significantly different at $\mathrm{P}<0.05$. 
With Spermidine

Without Spermidine

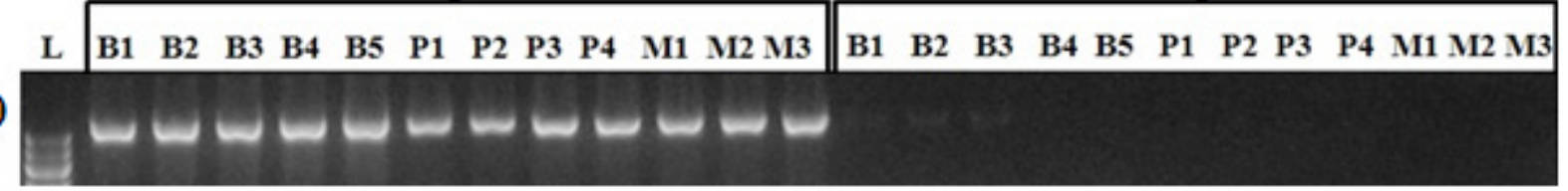

(B)

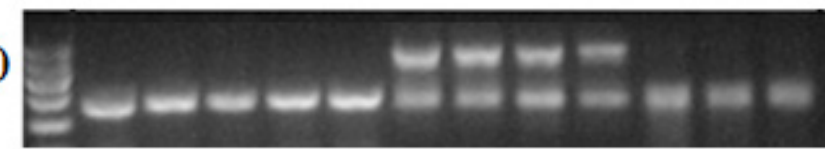

Figure 2: Comparison of the effect of spermidine in PCR amplification (A) plant barcoding region using rbcLprimer(550 bp band was detected). (B) SSR (300 bp band) and ISSR marker regions (300-600 bp band/s) L: 100 bp DNA molecular weight marker (cat no. QIAGEN 239035); B1, B2, B3, B4, B5: five elite selections of Bael; P1, P2, P3, P4: four selections of Pomegranate; M1, M2, M3: three selections of Mango.

cost methods preferred for large scale genotyping and other applications as commercial kits are not affordable in that context.

NanoDrop readings and agarose gel electrophoresis confirmed the presence of DNA in all the samples (Table 2 and Figure 1). For CTAB method, mostly low intense and smear like bands were observed (Figure 1A). However, the modified CTAB method showed significantly higher NanoDrop readings than those of commercial kits with mean DNA concentrations of $1233 \mathrm{ng} / \mu \mathrm{L}$ and $83 \mathrm{ng} / \mu \mathrm{L}$ respectively. Similarly, when same volumes of DNA loaded into an agarose gel, high intense bands were observed for CTAB method compared to kits (Figure 1B, 1C and 1D). NanoDrop readings of 260/280 and 260/230 values were more or less similar among different methods (Table 2). However, DNA extracted with CTAB method showed presence of relatively higher phenolic content and other low molecular weight contaminants (Figure 1B).

The original CTAB protocol (Doyle and Doyle, 1987) has modified a lot over time. Here, other than minor modifications in incubation time and volumes, the key modification was repeating the $24: 1$ chloroform/ isoamyl alcohol step. This additional step increased the quality of extracted DNA drastically, compared to single step. It is mainly due to removal of phenolic compounds and other secondary metabolites present in the samples. Though accuracy is less in spectrometer based concentration measurements, it is still used widely. According to the results, modified CTAB protocol has given significantly higher concentration of DNA compared to the commercially available kits with same amount of starting materials. Though there is no observable RNA contamination, there is little polyphenol or other substances remaining in the sample, appear as a smear. Higher concentrations achieved with modified CTAB protocol are obviously beneficial for applications such as genotyping needed to use the same sample with different primer combinations.

\section{PCR}

The universally accepted plant barcoding region; $r b c L$ has been amplified successfully from many plant species (Group, CBOL Plant Working et al 2009). However, neither modified CTAB extracted DNA samples nor the commercial kits successfully amplified the $r b c L$ region in the absence of spermidine (Figure 2A). However, inclusion of spermidine into the reaction had positive effect on PCR amplification and resulted the expected band of $\sim 550 \mathrm{bp}$ in all samples.

Both quality and quantity of DNA are critical for the applications such as SSR, ISSR and RAPD. Therefore, in addition to amplification of $r b c L$ region, same samples were amplified with either SSR or ISSR primers. While for bael, Rutaceae family specific SSR markers 12 (R) 13 (F) which supposed to result a $\sim 300$ bp fragment were used, mango samples were amplified with species specific SSR marker 84 (R \& F) with expected band size of 300 bp. Pomegranate DNA samples were amplified with ISSR primer 842 and it resulted two products in the range of 300 $-600 \mathrm{bp}$. As in the rbcL example, no PCR amplification was observed for SSR and ISSR for all samples without adding spermidine. Incorporation of spermidine resulted clear, repeatable amplification in all the samples (Figure 2B). The results confirm that the effect of remaining contaminants in DNA extracted with modified CTAB method could suppress with the inclusion of spermidine.

A concentration series of spermidine was tested with similar PCR conditions and $0.8 \mu \mathrm{M}$ was en-counted as the optimum concentration. Optimization of PCR amplification conditions by the addition of spermidine significantly enhanced the amplification of universally accepted bar coding region $r b c L$, SSR and ISSR markers in all three fruit species. Other than the selected species, PCR amplification of Gotukola (Centella asiatica), Kithul (Cryota urenus), Strobilanthes and Sandalwood (Santalum album) with high phenolic content was successful in the presence of spermidine (data not shown). Thus, the broad spectrum applications indicate that the possibility of routine supplement of spermidine for PCR reactions to overcome inhibition generated from secondary metabolites. Further, inclusion of spermidine had no negative effect on PCR reactions with high quality DNA extracted from species such as Arabidopsis or Oryza. Previous findings suggest that spermidine attenuate the DNA intercalater, actinomycin D, which is a natural inhibitor of transcription and replication (Wang et al., 2012). Further, the polyamines such as spermine and spermidine are known to induce autophagy in cell lines (Madeo et al., 2010), improve responses to chemotherapy (Allen et al., 2007) and found to present in 
breast milk as an important ingredient (Atiya-Ali et al., 2014).

Overall, optimized CTAB DNA extraction together with incorporation of spermidine successfully amplified relatively easy PCR reactions as well as difficult PCR reactions from all three plant species considered. Therefore, the results of this research provide evidence for the wide range of applications of optimized protocols, for different plant species and different types of PCR amplifications.

\section{CONCLUSIONS}

DNA extraction from the plant species that consist of high amount of phenolic compounds could be accomplished with all three extraction methods tested here. However, with the same amount of starting materials, the modified CTAB method yielded higher amount of total DNA than commercial kits, without sacrificing the quality. Inclusion of spermidine at the rate of $0.8 \mu \mathrm{M}$ improved the efficiency of PCR for easily amplifiable and difficult primer pairs in all the species reported. It could be concluded that, CTAB method with necessary modifications yields high quality DNA and the inclusion of spermidine facilitates successful amplification in PCR for all the three species implying the importance of alleviating PCR inhibitors.

\section{ACKNOWLEDGEMENTS}

Authors would like to acknowledge the financial assistance given by the National Science Foundation of Sri Lanka (Grant No: NSF/2015/BT/05), National Research Council of Sri Lanka (Grant No: 12-113) and the University Grant Commission of Sri Lanka (Grant No: UGC/VC/DRIC/ IRG/2014/PDN) for carrying out the research. Further, we would like to acknowledge the assistance given by Dr. (Mrs.) K.W. Ketipearachchi, Deputy Director, Mr. K.L. Gamlath of Department of Agriculture and the staff of the Fruit Crop Research and Development Institute, Department of Agriculture, Gannoruwa for providing plant materials. The staff members of the Agricultural Biotechnology Centre, Faculty of Agriculture, University of Peradeniya are also acknowledged for their assistance.

\section{REFERENCES}

Ahokas, H. and Erkkila, M.J. (1993). Interference of PCR amplification by the polyamlnes, spermine and spermidine. PCR Methods and Applications. 3: 65-68.

Allen, W.L., McLean, E.G., Boyer, J., McCulla, A., Wilson, P.M., Coyle, V., Longley, D.B., Casero-Jr. R.A. and Johnston P.G. (2007). The role of spermidine/ spermine $\mathrm{N}^{1}$-acetyltransferase in determining response to chemotherapeutic agents in colorectal cancer cells. Molecular Cancer Therapeutics. 6(1): 128-137.

Atiya-Ali, M., Strandvik, B., Sabel, K.G., Palme-Kilander C., Strömberg R. and Yngve A. (2014). Polyamine levels in breast milk are associated with mothers' dietary intake and are higher in preterm than full-term human milk and formulas. Journal of Human Nutrition and Dietetics. 5: 459-467.
Demeke, T. and Jenkins, G.R. (2010). Influence of DNA extraction methods, PCR inhibitors and quantification methods on real-time PCR assay of biotechnologyderived traits. Analytical and Bioanalytical Chemistry. 396(6): 1977-1990.

Doyle, J.J. and Doyle, J.L. (1987). A rapid DNA isolation procedure for small quantities of fresh leaf tissue. Phytochemistry Bulletin. 19: 11-15.

Fang, G., Hammar, S. and Grumet, R. (1992) A quick and inexpensive method for removing polysaccharides from plant genomic DNA. Biotechniques. 13(1)): 52-54.

Fredricks, D.N. and Relman, D.A. (1998). Improved amplification of microbial DNA from blood cultures by removal of the PCR inhibitor sodium polyanethol esulfonate. Journal of Clinical Microbiology. 36(10): 2810-2816.

Group, CBOL Plant Working, et al., (2009). A DNA barcode for land plants. Proceedings of the National Academy of Sciences. 106(31): 12794-12797.

Kikuchi, A., Sawamura, T., Kawase, N., Kitajima, Y., Yoshida, T., Daimaru, O., Nakakita, T. and Itoh, S. (2010). Utility of spermidine in PCR amplification of stool samples. Biochemical Genetics. 48(5-6): 428-432.

Kress, W.J. and Erickson, D.L. (2007). A two-locus global DNA barcode for landplants: The coding $r b c L$ gene complements the non-coding trnH-psbA spacer region. PLoS ONE. 2(6): e508. doi:10.1371/journal. pone. 0000508 .

Madeo, F., Eisenberg, T., Büttner, S., Ruckenstuhl, C. and Kroemer, G. (2010). Spermidine: a novel autophagy inducer and longevity elixir. Autophagy.6(1): 160-162.

Manoj, K., Tushar, B. and Sushama, C. (2007). Isolation and purification of genomic DNA from black plum (Eugenia jambolana Lam.) for analytical applications. International Journal of Biotechnology \& Biochemistry. 3(1): 49-55.

Mohammad, S.M. and Kashani, H.H. (2012). Chemical composition of the plant Punica granatum L. (Pomegranate) and its effect on heart and cancer: a review. Journal of Medicinal Plants Research. 6(40): 5306-5310.

Ono, N.N., Bandaranayake, P.C.G. and Tian, L. (2012). Establishment of pomegranate (Punica granatum) hairy root cultures for genetic interrogation of the hydrolyzable tannin biosynthetic pathway. Planta. 236(3): 931-941.

Pirttilä, M.A., Hirsikorpi, M., Kämäräinen, T., Jaakola, L. and Hohtola A. (2001). DNA isolation methods for medicinal and aromatic plants. Plant Molecular Biology Reports. 19(3): 273a-273e.

Roperch, J.P., Benzekri, K., Mansour, H. and Incitti, R. (2015). Improved amplification efficiency on stool samples by addition of spermidine and its use for non-invasive detection of colorectal cancer. $B M C$ Biotechnology. 15(1):41.

Roychowdhury, R., Karmakar, J. and Dey, N. (2012). PCRcompatible genomic DNA isolation from different tissues of rice (Oryza sativa) for SSR fingerprinting. EurAsian Journal of BioSciences. 6: 85-90.

Sahu, S.K., Thangaraj, M. and Kathiresan, K. (2012). 
DNA extraction protocol for plants with high levels of secondary metabolites and polysaccharides without using liquid nitrogen and phenol. ISRN Molecular Biology. Article ID 205049, doi:10.5402/2012/205049.

Schrader, C. and Schielke, A., Ellerbroek L. and Johne R. (2012). PCR inhibitors - occurrence, properties and removal. Journal of Applied Microbiology. 113: 10141026.

Shah, M.B., Patel, M.B., Patel, R.J. and Parmar, P.K. (2010). Mangifera indica (Mango). Pharmacognosy Review. 4(7): 42-48.

Viuda-Martos, M., Fernández-López, J. and Pérez-Álvarez, J.A. (2010). Pomegranate and its many functional components as related to human health: a review. Comprehensive Reviews in Food Science and Food Safety. 9: 635-654.

Wan, C.Y. and Wilkins, T.A. (1993). Spermidine facilitates
PCR amplification of target DNA. Cold Spring Harbor Laboratory Press. ISSN 1054-9803/93: 208-210.

Wang, S.Y., Lee, Y.L., Lai, Y.H., Chen, J.J.W., Wu, W.L., Yuann, J.M.P., Su, W.L., Chuang, S.M. and Hou, M.H. (2012).S permine attenuates the action of the DNA intercalator, actinomycin D, on DNA binding and the Inhibition of transcription and DNA replication. PLOS ONE. 7(11): e47101.

War, A.R., Paulraj, M.G., Ahmad, T., Buhroo, A.B., Hussain, B., Ignacimuthu, S. and Sharma, H.C. (2012). Mechanisms of plant defense against insect herbivores. Plant Signaling \& Behavior. 7(10): 1306-1320.

Yadav N.P. and Chanotia C.S. (2009). Phytochemical and pharmacological profile of leaves of Aegle marmelos Linn. The Pharma Review 2009: 144-149. 